\title{
Fiscal Policy Framework in West African Monetary Zone (WAMZ): The Matter of Debt Sustainability
}

\author{
Abdoulkader Houssein Mohamed ${ }^{1}$ \\ ${ }^{1}$ School of Finance, Zhongnan University of Economics and Law, Wuhan City, China \\ Correspondence: Abdoulkader Houssein Mohamed, School of Finance, Zhongnan University of Economics and \\ Law, Wuhan City, 430073, China. E-mail: abdohoussein@hotmail.fr
}

Received: July 8, 2014

doi:10.5539/ijef.v6n11p60
Accepted: August 22, 2014

Online Published: October 25, 2014

\begin{abstract}
Fiscal sustainability issue is one of the major concerns in macroeconomics. This article seeks to study the sustainability of fiscal policy of six composing members in West African Monetary Zone with the trend of public finance and debt management over a period 1985-2013. We employed unit root and cointegration test to apply the requirement of the present value of budget constraint. This methodology is generally used in the empirical analysis of the historical fiscal sustainability process. To determine this scenario, three variables (GDP, deficit, debt) have been used, in some points the outcome showed that debt is sustainable in Gambia, Ghana, Guinea, Nigeria and Sierra Leone but not in Liberia.
\end{abstract}

Keywords: West African monetary zone, present value, government debt, deficit

\section{Introduction}

Number of studies has been carried out on currency union. Some scholars have paid attention to fiscal policy; crisis, neglect, deficit, integration (cf. Jordi \& Tommaso, 2008; Paul \& Catherine, 2003; Betty, 2000; Jan Libich, Jame \& Petr, 2010; Russell, 2002) and the optimality but not much on the sustainability issue which remains challenging to be achieved in an agreed-upon single currency zone. Few scientific studies have addressed the sustainability issue in the case of African Economies. The sustainability issue is paramount for the countries which face a history of a long run budget deficit (Note 1), debt burden and macroeconomic instability; this motivates the study. The purpose of this paper is to study fiscal sustainability (components, effects and measures) and to assess the current position of WAMZ.

The paper is structured as follows: Section 2 provides the theoretical framework about the concept and the components of fiscal sustainability as well as the literature review exposed by different researchers from which we will find out the appropriate methodology. Section 3 gives an overview of fact in WAMZ, addresses their current fiscal position, the chosen policies and debt sustainability. Section 4 indicates the methodology used in this case which is Unit Root Test and Cointegration Test. Section 5 draws empirical result and finally section 6 mentions the obtained conclusion.

\section{Literature Review}

\subsection{Theoretical Literature Review}

The challenge of a sustainability stems from the magnitude of indebtedness and deficit of a country which must be monitored by supranational institution regards to its budget management. Each member must perform a sustainable debt ratio (Note 2); it is called for meeting a solvent level to maintain over a period of time the budget surplus higher than the amount of the borrowing and interest rate. In addition country is supposed to stabilize its ratio of debt to GDP without using fiscal policy for any significant adjustment. Because adjustment deepens the budget deficit with additional flow of external borrowing, then as a result the external debt will be accumulated as well as the debt will be no more sustainable. But, governments meet the restrictions to how much they can borrow because they deal with a present-value borrowing constraint; in other words, governments should intertemporally weight their budgets by fixing the current market value of debt equal to the discounted sum of expected future surpluses (Stefan Collignon). A non-compliance of intertemporal budget balance would show that the fiscal policy may not be sustained much longer, since the value of debt would go off over time at a rate faster than the growth rate of the economy. 
Then if debt is no more sustainable it will generate a negative impact on the economy, it plays central role for well-functioning of the entire economy. Fiscal deficit of one country will cause negative externalities in the monetary union area and plead to a tight monetary policy. As a result it will lead to the increase of the interest rate, cut in public investment and undermines the economic growth for all members. Contrary in the longer term an expansionary monetary policy will be set off through the central bank to back the fragile domestic economy which means to finance the budget deficit. More money in circulation fuels higher price level and the increasing volume of domestic credit encourages imports, this channel (Oshikoya) reduces the amount of foreign exchange available resulting in a fall in months of import cover. As a consequence domestic financing is likely to increase pressure in exchange rate depreciation.

From sustainability issue let's discover what the risk is in a currency union. Daniel and Schiamptanis determined how this risky position occurs and paid attention to a position where the upper bound to debt/deficit does not afford facing stochastic shocks. Furthermore any government could face a situation where the expected surpluses would be lower than debt and unable to find the needed funds for taking on fiscal adjustment against the external shocks. Besides being short of additional resource, the interest rate increases, then government would not be granted again to borrow because the amount of the debt exceeds the value of expected surpluses. In the end without fresh capital inflow into the budget, the higher level debt will cause a fiscal crisis with costly consequences as default, bail out and negative spillover.

\subsection{Empirical Literature Review}

Through literature, fiscal sustainability in a monetary union was subject of several studies in a different point of view. The classic test is that of Hamilton and Flavin (1986), who implemented the Flood-Garber (1980) test for price bubbles to the PVBC for the postwar United States. These two authors chose as variables real primary surplus, seigniorage and real debt stock. Testing this methodology using the US data from 1960 to 1981, they found that the US budget balance presented a long-run sustainable path, despite its systematic budget deficits. Xiomara Archibald and Kevin Greeindge (2003) used accounting, PVBC and TVC approach to test fiscal sustainability involving a test of stationary and cointegration a set of variables such as fiscal deficit, revenue and expenditure. Employing these methodologies to the BABADOS data from 1974-2001, these authors found that the fiscal policy since independence has in fact been sustainable and the government has consistently adhered to its budget constraint.

Antonio Afonso (2000) wrote a paper called "fiscal policy sustainability, some unpleasant European evidence". To assess the sustainability of budget deficits in the Euro area, stationary test for the stock of public debt and co-integration test between public expenditures and public revenues was done for the Euro countries for the 1968-1997 periods, he alluded to PVBC methodology. The findings indicate a sufficient condition for fiscal policy sustainability was accepted in three countries: Germany, Austria and Netherlands. Continuously Antonio Afonso (2004) in his scientific work evaluated the sustainability of budget deficits in the EU countries during the 1970-2003 periods. As for econometric model, he exploited the co-integration tests between public expenditures and public revenues. In his empirical results Antonio found with few exceptions fiscal policy may not has been sustained. EU governments therefore might risk becoming inherently highly indebted even if the debt-to-GDP ratios seemed to be somehow stabilizing at the end of the 1990s.

\section{Overview of the Fact in WAMZ}

This section reviews the performance of fiscal policy and debt sustainability in WAMZ countries.

Table 1. Government debt (Note 3), percent of GDP

\begin{tabular}{ccccccc}
\hline & Nigeria & Ghana & Gambia & Guinea & Liberia & Sierra Leone \\
\hline $\mathbf{2 0 0 4 - 2 0 0 8}$ & 23.6 & 39.3 & 108.6 & 117.9 & 608.4 & 94 \\
$\mathbf{2 0 0 4}$ & 52.7 & 57.4 & 133.2 & 119.8 & 829.9 & 151.6 \\
$\mathbf{2 0 0 5}$ & 28.6 & 48.2 & 132.4 & 150.2 & 734.9 & 130.9 \\
$\mathbf{2 0 0 6}$ & 11.8 & 26.2 & 142.6 & 137.1 & 665.9 & 103.1 \\
$\mathbf{2 0 0 7}$ & 12,8 & 31 & 63 & 92.4 & 495.9 & 42.2 \\
$\mathbf{2 0 0 8}$ & 11.6 & 33.6 & 72 & 90.2 & 315.7 & 42.4 \\
$\mathbf{2 0 0 9}$ & 15.2 & 36.2 & 69 & 89.3 & 171.4 & 48.1 \\
$\mathbf{2 0 1 0}$ & 15.5 & 46.3 & 70.5 & 99.6 & 31.6 & 46.8 \\
$\mathbf{2 0 1 1}$ & 17.2 & 43.7 & 76.6 & 77.8 & 29.8 & 44.4 \\
$\mathbf{2 0 1 2}$ & 18.3 & 50.2 & 79.2 & 35.4 & 29.1 & 36.7 \\
\hline
\end{tabular}




\begin{tabular}{ccccccc}
\hline $\mathbf{2 0 1 3}$ & 19.6 & 51.2 & 79.5 & 36.9 & 26.9 & 35.2 \\
$\mathbf{2 0 1 4}$ (Note 4) & 20.3 & 53.8 & 72.6 & 36.8 & 30.4 & 33.8 \\
\hline
\end{tabular}

Source: IMF (2013), Regional Economic Outlook: Sub-Saharan Africa.

\subsection{Debt Sustainability (Note 5)}

The scenarios evidently pointed out for the countries that depend considerably on grants implicate the set conditions are going to be challenging as regards how to finance and to make sustainable the budget. Meanwhile Government debt of Gambia reached 79, 2\% of GDP in 2012 above the threshold of $60 \%$, fueled mainly by the increase of domestic borrowings, recorded as the highest one in WAMZ. In DSA evaluation, Gambia has moderate risk of debt distress compare to external debt indicator; this country has improved debt management and carries on the medium-term strategy. The debt sustainability remains below the expected values, this situation won't last any longer in case of new borrowing and adverse shocks that impact the agriculture production.

Nigeria recorded the lowest ratio of debt to GDP (18.3\% in 2012) and maintained an affordable ratio over the past 10 years. This country adopted a strategic focus toward strengthening the domestic bond market to hold up private sector development and provide low-cost funding for public projects. The debt is ranked at a low risk but once again a continuous negative oil price shock may weaken the progress has been made so far.

Liberia somehow recovered from war since it carried out strong performance during the post-war period based on iron ore exports, construction and foreign direct investment. Liberia's debt outlook has been positive since reaching the Heavily Indebted Poor Countries (HIPC) Initiative completion point in 2010. Government debt undertakes a series of rules, specified both in the Public Financial Management (PFM) Act and as part of the IMF Extended Credit Facility (ECF) Program which include preserving annual borrowing below 4\% of GDP on an NPV basis and keeping the debt stock under $60 \%$ of GDP, in final Liberia manages well the risk of debt too.

Ghana's debt has stabilized around 50\% of GDP since 2012 and progressed in reinforcing its debt management skills and policies, following the organizational reforms under way in the Aid and Debt Management Unit since 2010. In 2011, the unit published 2012-14 Medium Term Debt Management Strategy targeted to ensure prudent levels of risk, keep up the public debt at sustainable levels over the medium to long term and deepening the domestic debt market. The government debt burden reduced after the completion of the HIPC initiative in 2002/2003 and more can be achieved after further fiscal consolidation.

Guinea has been going on in debt distress since 2007 as it can be certified with the accumulation of external debt service arrears. In 2011 the debt burden indicators related to PV of external debt are evaluated to be over the policy thresholds. More accurately, the PV of external debt-to-GDP ratio is 41.3 percent (threshold: 30 percent); the PV of debt-to-exports ratio is 137 percent (threshold: 100 percent); and the PV of debt-to revenue ratio is 234 percent (threshold: 200 percent). The indicators relating to debt service were below the policy thresholds. If there are no HIPC/MDRI debt relief and decrease of public expenditure, Guinea is at high risk of debt distress then remain vulnerable to adverse shocks.

Sierra Leone published a risky debt and could be riskier since the long run debt outlook shows vulnerability to adverse shocks related to some keys macroeconomic variables particularly growth, exports, inflation, FDI inflows and fiscal primary balance. This underlines among others the necessities to carry on fiscal consolidation efforts, eliminate obstacles to growth, reinforce export diversification and continue prudent borrowing policies. Debt relief occurs in recent years has reduced Sierra Leone's burden. But long-run debt sustainability risk could be avoided in case that the financing needs would keep on to be covered principally through grants and highly concessional loans. This shows likewise Sierra Leone's vulnerability to adverse exogenous shocks.

Generally speaking, mean value of government debt for whole West African Monetary Zone decreased below 50\% of GDP and it shows that they brought the debt issue under control. Their debt policies resulted in efficient strategies by targeting a viable position since they are all converging as for debt sustainability. 


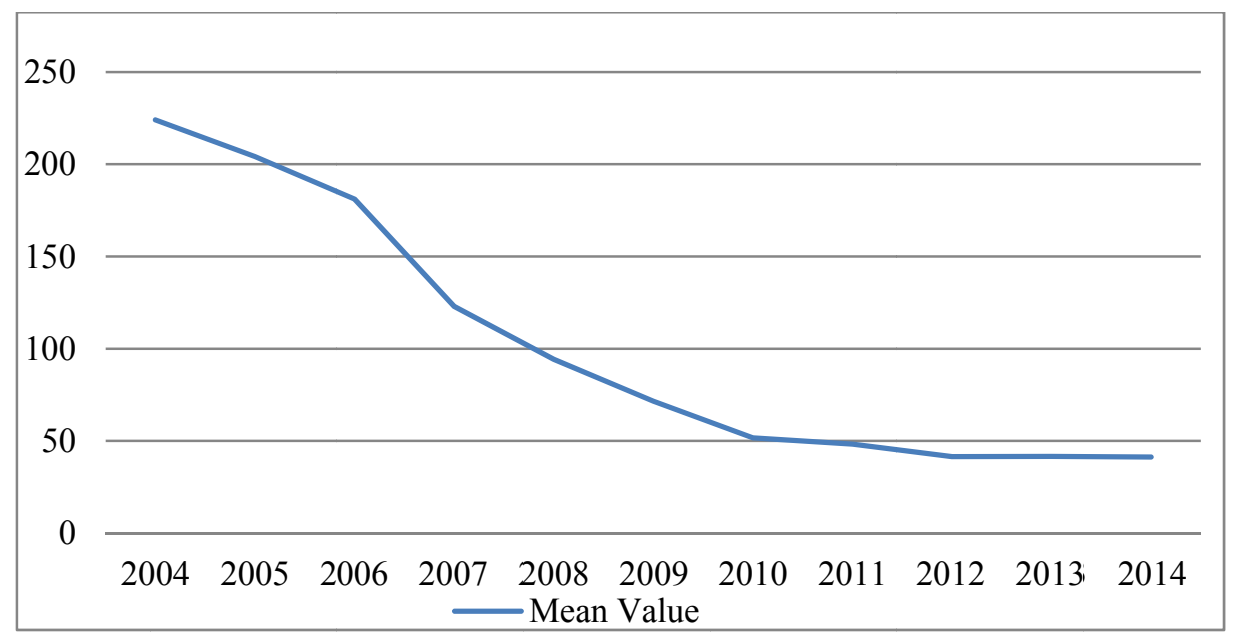

Figure 1. Trend of governement debt as ratio to GDP in WAMZ

Source : Author's Calculation from IMF (2013).

\subsection{Fiscal Policy}

Ghana: Fiscal policy aims of this country are mainly to mobilize more fiscal resource; allocate and run financial resources efficiently and rationally; shrink the debt weight and finally make stronger the private sector. Therefore, the fiscal policy construction is set to reach out macroeconomic stability so that to sustain economic growth and development. In 2012 the deficit has increased to $4.9 \%$ of GDP and then predicted to decrease to $3.5 \%$ in 2013 and $3 \%$ in 2014 . The Key challenges to the implementation of fiscal policy are to deal with a higher wage expenditures and energy subsidies. The government engages effort to observe fiscal prudence by resisting pre-election spending pressures which shakes the stability.

The government faces arrears management carries on to be challenged even after the set up of commitment controls and an arrears clearance strategy. Because the arrears amassing lead to a negative impact on the economy through the constraints of private sector activity and a positive impact on bank' non-performing loans. The 2012 budget released a set of additional revenue-enhancing measures since 2009 Ghana Revenue Authority reforms.

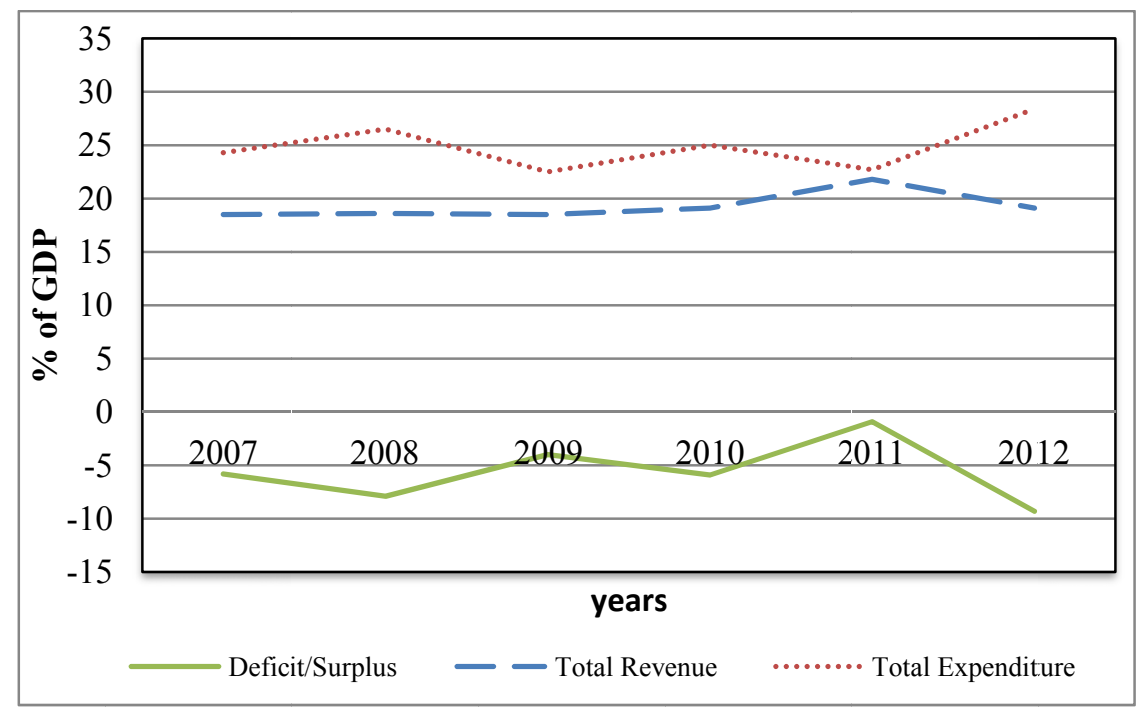

Figure 2. Fiscal deficit (\% of GDP) GHANA

Source: WAMI, 2011 and African economic outlook, 2012.

Nigeria: Fiscal policy is intended to boost investment in some sectors of the economy with the goal of ensuring 
macroeconomic stability and fiscal consolidation. As measures the Federal Executive Council (FEC) chose a close debt management framework requiring a strategy to guarantee efficient public debt management as regard an inclusive well-diversified and sustainable portfolio and that support government and private sector needs.

As taken measures, in January 2012 the Nigerian governments suppressed the subsidy on petrol because of generated cost (4.2\% of GDP in 2011) and lack of efficiency. Then the government reoriented savings from the partial removal of the fuel subsidy into social safety net programs and key infrastructure projects through a subsidy reinvestment and empowerment program (SURE-P). The government is investing in key sectors consistent with the objectives of its transformation agenda. External financial assistance to Nigeria is very small relative to the country's own resources. The government has been worried about the increasing debt stock focused on its domestic component.

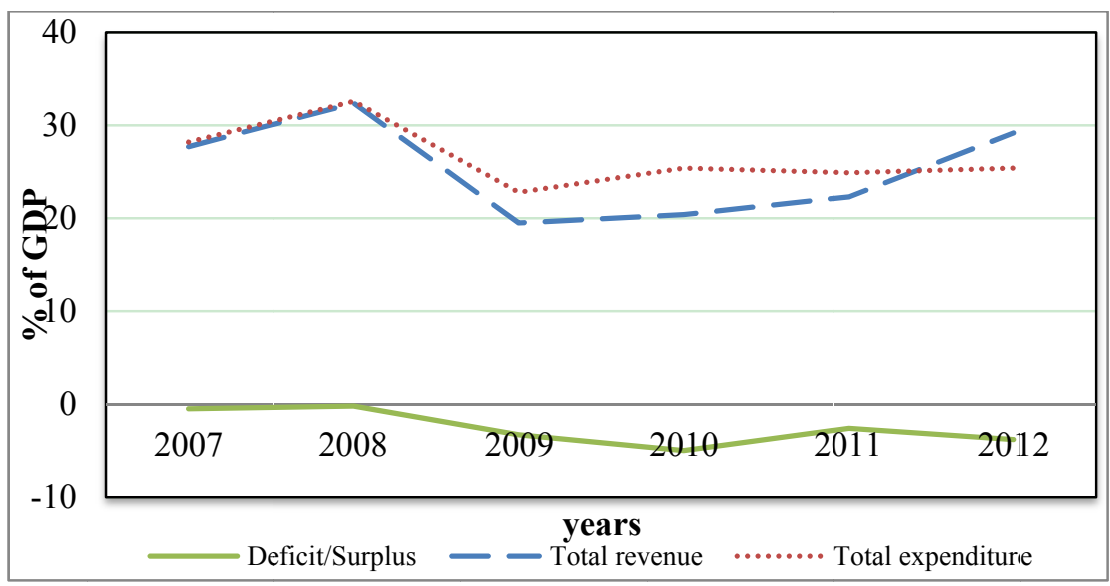

Figure 3. Fiscal deficit (\% of GDP) Nigeria

Source: WAMI, 2011 and African economic outlook, 2012.

Gambia: The government targets the development of public and private sector investment on its way to attempt a satisfactory economic growth in accordance with fiscal consolidation. The government's initiatives to make better revenues and taxpaying are not running as expected proved through taxes evasion and avoidance. This explains in part why Gambia has one of the highest taxation rates in the region. The government projects to keep on the reforms in tax policy and revenue administration to inflow more revenues, gain efficiency and get better business environment. It has also set up a smooth introduction of the VAT in sequence with its commitments to the Economic Community of West African States (ECOWAS).

In the same way, the government's action on expenditure is still weak. For instance total expenditure and net lending rose in 2012 from $25.9 \%$ of GDP to $25.7 \%$ in 2011 . To satisfy Net Domestic Borrowing (NDB) goal, the government pursues to use a cash budgeting approach that have expenditures controlled.

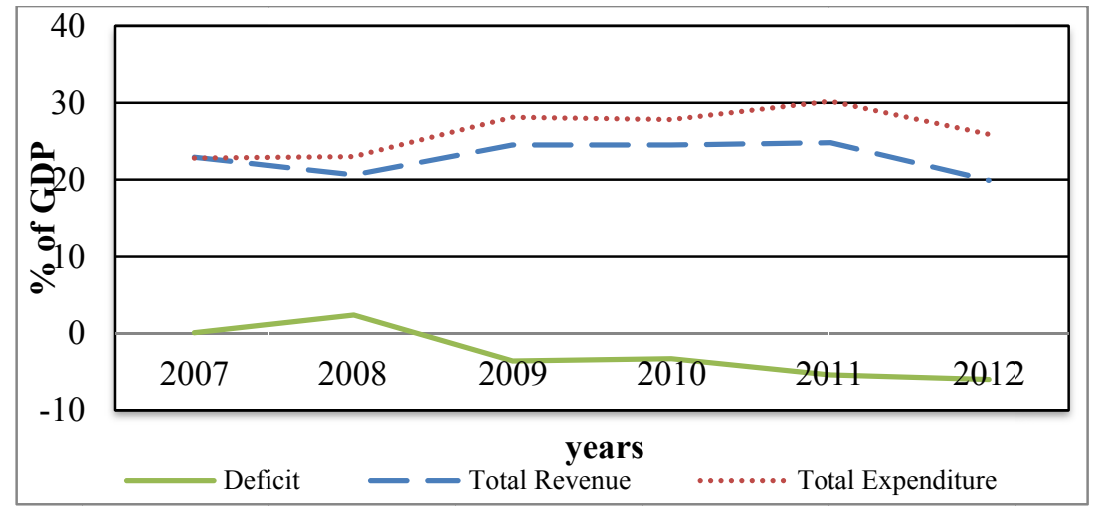

Figure 4. Fiscal deficit (\% of GDP) GAMBIA

Source: WAMI, 2011 and African economic outlook, 2012. 
Guinea: Stabilize the macroeconomic environment and boost economic growth by reducing the fiscal deficit and increasing public investment. To manage the debt, they emphasize on finding external funds at concessional rates and restraining domestic borrowing from the BCRG.

In terms of fact, fiscal fees in 2012 increased to $19.9 \%$ of GDP from $15.6 \%$ in 2011 , boosted mainly by the growth in revenues from oil-related products and income produced by foreign trade. In order to increase domestic revenue, challenges of fraud and the weakness of the institutional capacities of the tax and customs administrations should be taken. The expenditures are predicted to remain high, due partly to the pay rises after the government and trade unions gave their agreement at the negotiation in 2012. The concentration on monitoring the expenditure and initiatives to increase revenues maintained the overall budget deficit under control (0.3\% of GDP in 2011 and $1.4 \%$ in 2012.

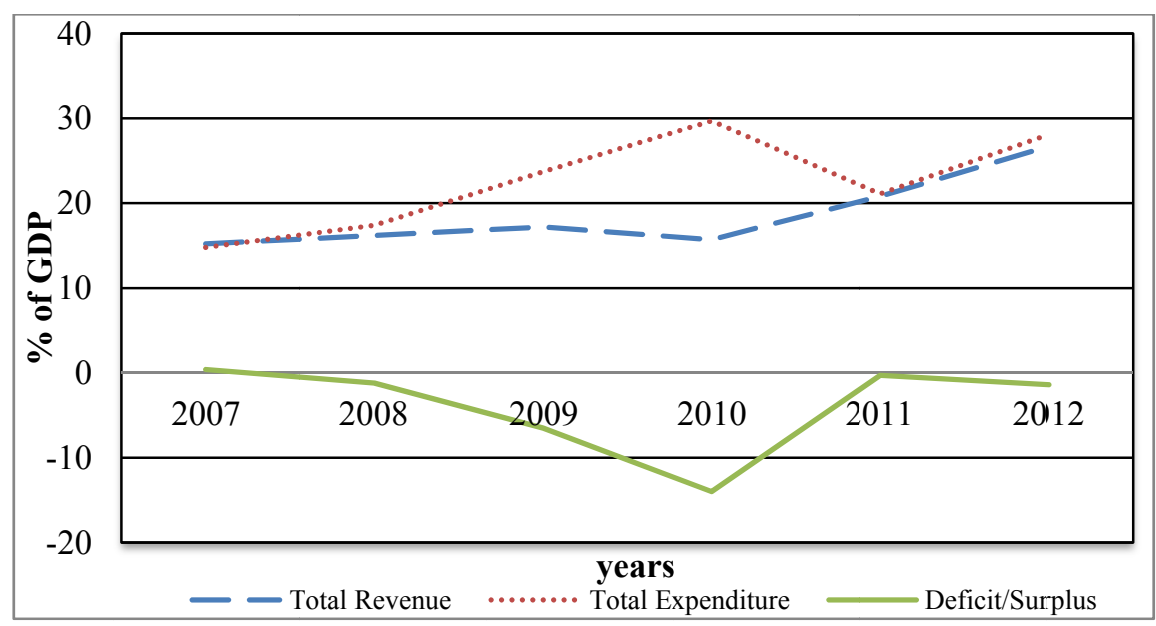

Figure 5. Fiscal deficit (\% of GDP) Guinea

Source: WAMI, 2011 and African economic outlook, 2012.

Sierra Leone: this country's aims are to design and set up sound economic policies but also manage efficiently public finance so that to guarantee efficient allocation of resources to promote steady economic growth and development in the situation of a stable macroeconomic framework. The government needs to take action for the availability of infrastructures, spread out the social service while preserving macroeconomic stability.

The overall fiscal deficit is evaluated to $1.8 \%$ in 2012 downed by a rigid fiscal policy and strengthened by the fiscal discipline. To reinforce fiscal policy application, the government has adopted a lot of measures in 2012 as such we can quote: preparation and execution of monthly cash flow statements reflecting expenditure priorities and financing constraints, tightening of the expenditure commitment process to contain non-priority spending or postponement of a wage increase, pending the assessment of savings from the implementation of the pay reform. As a result we notice an increase of revenue collection even if it is slight compared to GDP growth. 


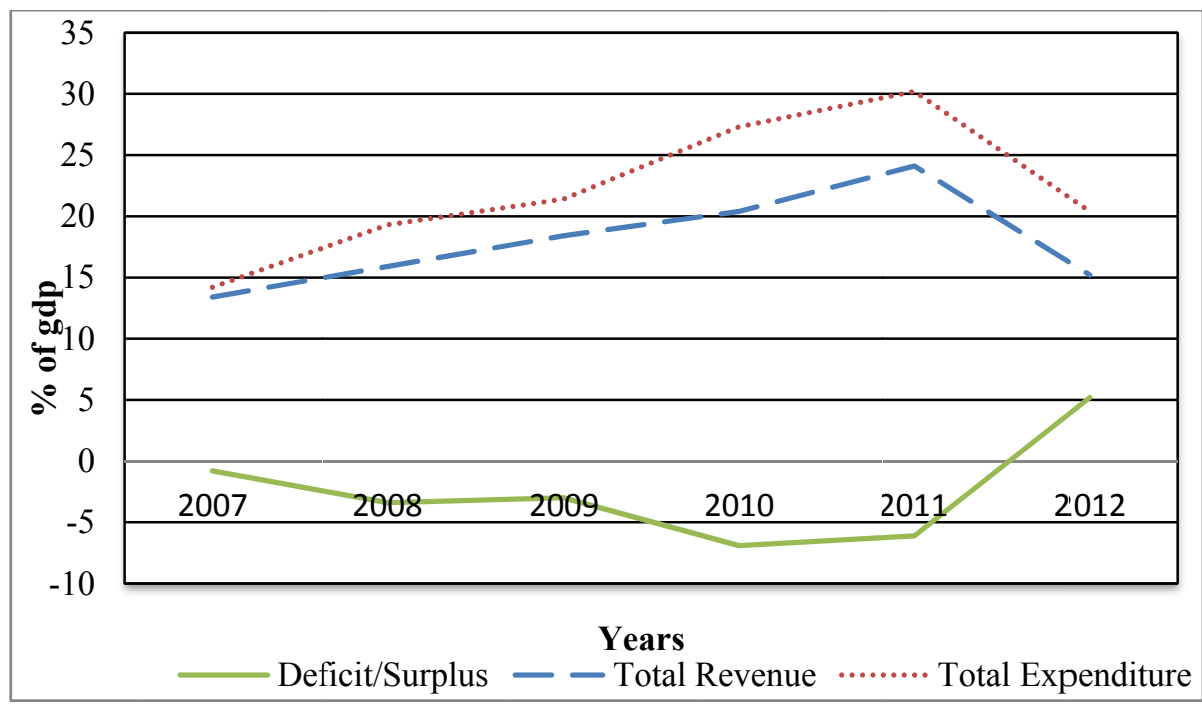

Figure 6. Fiscal deficit (\% of GDP) Sierra Leone

Source: WAMI, 2011 and African economic outlook, 2012.

Liberia: it is more towards strong and sustained economic growth in order to lower poverty, good service provision and gathering resources. The government targets to augment investments and increase living standard of people.

Government budgets increase sharply since 2008, the economy expansion has led to the expansion of public service. The government intends to finance primary deficit through concessional lending for majors projects. It was prepared for the first time as a Medium Term Expenditure Framework (MTEF), covering the current year's budget and estimates for the next two years, with expenditure aligned with the Agenda for Transformation. The last budget splits out recurrent and project spending, which result in an increased reducing basic spending permitting for increased investment.

Actually these basic or recurrent expenditure was reduced over the previous year to allow for more investment in key infrastructure projects, as a result, capital expenditure is expected to increase, implementation of investment projects has been slowed by capacity constraints, a shallow private sector, and slow procurement processes. To avoid debt accumulation in MTEF government intends to finance projects through taxes and grants. Therefore fiscal rules were proposed to maintain capital spending at or above $25 \%$ of budget and constrain wage costs to no more than $34 \%$.

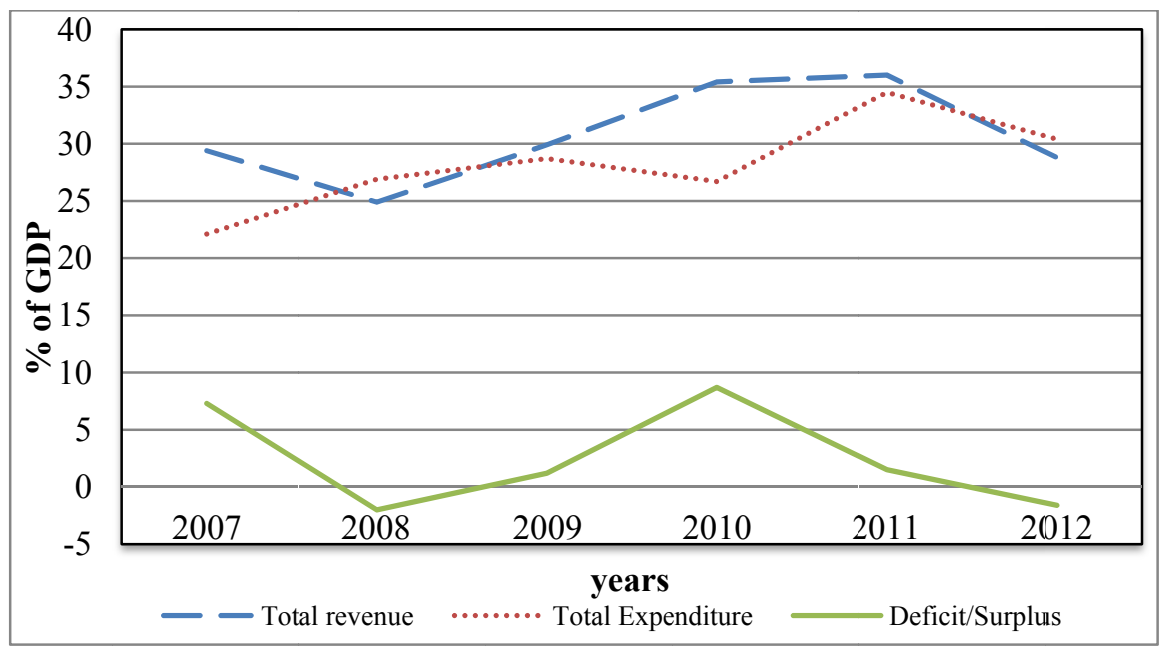

Figure 7. Fiscal deficit (\% of GDP), Liberia

Source: WAMI, 2011 and African economic outlook, 2012. 


\section{Methodology}

All studies of sustainability begin with the dynamic government budget constraints. Its classic definition is as follows: consider B nominal debt, $i$ the nominal interest rate on the debt, G nominal government spending on goods and services, $\mathrm{H}$ transfers and $\mathrm{T}$ taxes. Then, the change in the nominal value of the debt is set by:

$$
d B / d s=G+H-T+i B
$$

The value of spending plus transfers minus taxes is mostly pertains to as the primary deficit. It will play a major role below, and the right hand side of this equation matches to the ordinary definition of the deficit. As economy and econometrics studies are growing, they realized it is much consistent to reconsider budget constraints in perspective of present discounted value. This method requires that debt ratio to GDP eventually converge back to its initial level that is to say future primary budget balances must at least be equal to the value of the stock of debt. Since fiscal sustainability relies on a country ability to abide by Present Value of budget constraints (PVBC).

Cunddington (1996) considers two commonly used approaches to evaluating fiscal sustainability: accounting approach and the econometric approach, also termed the present value constraint (PVC) approach. The starting point of both approaches is the balance sheet of the consolidated public sector or the government budget constraint as shown in Equation 2:

$$
G_{t}-R_{t}+i_{t-1} B_{t-1}=B_{t}-B_{t-1}+M_{t}-M_{t-1}
$$

Here Gt, Rt, Bt, Mt and they are respectively government expenditure, government revenue, government debt, money supply, and the interest rate, all in nominal terms at time t. Let the primary balance (S) be equal to government revenue less expenditure (R-G), and substitute for $\mathrm{S}=\mathrm{R}-\mathrm{G}$ to get:

$$
\text { - } S_{t}+i_{t-1} B_{t-1}=B_{t}-B_{t-1}+M_{t}-M_{t-1}
$$

According to accounting approach it attempts to determine the sustainable fiscal deficit by making assumptions that liabilities can continue to grow at the growth rate of the economy's GDP, so that debt/GDP ratios remain constant. Accounting approach assessing fiscal sustainability involves econometric testing of the stationary (unit root) and cointegration properties of primary properties according to the variables chosen by some studies. Among many studies, we keep the one matching to my case, then Hamilton and Flavin in 1986 evaluated through two phases: first we test whether $S_{t}$ and $B_{t}$ are first order of integration I (0). If both variables are stationary and I (1), we continue to test with cointegration the following regression model (Temitope W. Oshikoya, Abu Bakarr Tarawalie and Rohey Khan, 2010):

$$
S_{t}=\beta_{0}+\beta_{1} B_{t}+\mu_{t}
$$

$\mathrm{S}_{\mathrm{t}}$ expresses the primary balance with grant not included, $\mathrm{B}_{\mathrm{t}}$ is total debt, $\mu_{\mathrm{t}}$ is the error term independently distributed with mean zero and constant variance.

\subsection{The Process to Unit Root Test}

For time series data the most adapted econometric models are Unit Root test, it is used to find out later if two variables are cointegrated. The traditional process to test the likelihood of fiscal crisis requires an examination through a check using Augmented Dickey-Fuller (ADF) test. The data covers a sample of 6 countries (Ghana, Nigeria, Sierra Leone, Guinea and Gambia) and quantitative annually-dated on total debt (domestic debt + external debt) and the fiscal deficit (surplus) over a period of 1985-2013. Debt is regarded as independent variable and Deficit/Surplus as dependent; therefore we seek to identify the relationship between them computed all as a ratio of GDP. All these data are released by the IMF, WAMI, African economic outlook and national authorities. We test two hypotheses:

$>$ Ho: Variables are not stationary then the series contain unit root

$>\mathrm{H} 1$ : Variables are stationary then the series do not contain unit root.

Technically there is unit root if Augmented Difference (ADF) is higher than Critical Value (CV) in the design of the model and vice versa.

\subsection{The Process to Cointegration Test}

By sticking to accounting approach of the present value of budget constraints, some basic rules are set: the sustainability issue requires all variables to be integrated of order one, I (1) and come to the results whereby we see cointegration between them. If it is not so we assume that fiscal issue isn't sustainable. When the two variables have different order of integration it means no long-term relationship between them and the violation of PVBC. The cointegration between variables is tested by performing the Johansson Likelihood technique, the 
Johansen test uses the VAR method, in which all cointegrated two series are considered endogenous, the likelihood ratio test (LR) was used conducted with an appropriate lag length as our model case it is one. If the LR value exceeds the critical value, then no cointegration is revealed but if critical value exceeds LR value we notice the existence of cointegration. Let's process the outcome

\section{Empirical Result}

Table 2. Unit root tests using the Augmented Dickey-Fuller test

\begin{tabular}{lcccccc}
\hline & Gambia & Ghana & Guinea & Liberia & Nigeria & Sierra Leone \\
\hline Var. 1 : Fiscal Deficit (Surplus) & & & & & & \\
No trend; No Intercept & & & & & & \\
Level & -0.924 & -0.34 & -1.00 & -1.55 & $-2.64^{*}$ & $-3.11^{*}$ \\
$\quad$ st difference* & -3.89 & -7.21 & -4.17 & -2.89 & 0 & \\
Order of Integration & $\mathrm{I}(1)$ & $\mathrm{I}(1)$ & $\mathrm{I}(1)$ & $\mathrm{I}(1)$ & $\mathrm{I}(0)$ & $\mathrm{I}(0)$ \\
Trend ; Intercept & & & & & & \\
Level & -2.88 & -2.43 & -2.73 & -2.14 & -2.51 & -3.05 \\
$1^{\text {st difference }}$ & $-3.51^{*}$ & $-7.04^{*}$ & $-5.70^{*}$ & $-5.48^{*}$ & $-4.86^{*}$ & $-5.34^{*}$ \\
Order of Integration & $\mathrm{I}(1)$ & $\mathrm{I}(1)$ & $\mathrm{I}(1)$ & $\mathrm{I}(1)$ & $\mathrm{I}(1)$ & $\mathrm{I}(1)$ \\
Var.2 : Government Debt & & & & & & \\
No Trend; No Intercept & & & & & & \\
Level & -0.8 & -0.48 & -0.64 & -4.74 & $3.3^{*}$ & $-1.96^{*}$ \\
1st difference & -3.94 & -3.09 & -3.27 & -1.95 & & \\
$\quad$ Order of Integration & $\mathrm{I}(1)$ & $\mathrm{I}(1)$ & $\mathrm{I}(1)$ & $\mathrm{I}(1)$ & $\mathrm{I}(0)$ & $\mathrm{I}(0)$ \\
Trend; Intercept & & & & & & \\
Level & -2.35 & -2.82 & -0.47 & -1.83 & -0.41 & -1.74 \\
1st difference & $-3.66^{*}$ & $-3.46^{*}$ & $-4.80^{*}$ & $-2.13^{*}$ & $-3.86^{*}$ & $-5.12^{*}$ \\
Order of Integration & $\mathrm{I}(1)$ & $\mathrm{I}(1)$ & $\mathrm{I}(1)$ & $\mathrm{I}(1)$ & $\mathrm{I}(1)$ & $\mathrm{I}(1)$ \\
\hline
\end{tabular}

Note. *significant at $1 \%, 5 \%$ and $10 \%$.

Empirical results indicates almost similar statement which implies that all six countries represent both the critical value higher than the amount of ADF as indicated in Table 2. Therefore both of the variables are integrated of the first order. Generally speaking since ADF T-statistic value is lower than CV we rejected the null hypothesis and accepted hypothesis one meaning the two time series does not change as time goes on.

\subsection{Cointegration Analysis}

According to the set rules, since all are first order integration it describes that debt and deficit are growing at the same rate. The methodology of the present value of budget constraint demands the budget position to cover up the future trend of government debt by being sustainable through cointegration test. The outcome revealed the existence of cointegration in all countries but Liberia results in that debt is sustainable because p-value is less than $5 \%$ or $1 \%$.

In Ghana, the outcome points out the existence of cointegration between fiscal deficit and total debt. We conclude that during the reference period, Ghana government can still grant additional external borrowings and then has a solvency capacity. This performance arises from tight fiscal policy set last couple years plus the increasing export earnings. The debt relief granted to the HIPC completion point has lifted the debt burden as well. Increased oil (recently discovered) production is projected to keep the growth rate at a good level and revenue inflow into the budget. However according to CPI Ghana faces high inflation spiral, double digit, and would have an impact on interest rates. 
Table 3. The cointegration test outcome

\begin{tabular}{|c|c|c|c|c|c|}
\hline Eigen value & $\begin{array}{l}\text { Likelihood } \\
\text { Ratio }\end{array}$ & $\begin{array}{l}5 \text { Percent } \\
\text { Critical Value }\end{array}$ & $\begin{array}{l}1 \text { Percent } \\
\text { Critical Value }\end{array}$ & $\begin{array}{l}\text { Hypothesized } \\
\text { No. of CE(s) }\end{array}$ & \\
\hline \multirow[t]{2}{*}{ Gambia (1) } & 0.817012 & 20.34771 & 15.41 & 20.04 & None** \\
\hline & 0.140545 & 1.666023 & 3.76 & 6.65 & At most 1 \\
\hline \multirow[t]{2}{*}{ Ghana (2) } & 0.49119 & 19.88905 & 15.41 & 20.04 & None* \\
\hline & 0.204184 & 5.024511 & 3.76 & 6.65 & At most $1^{*}$ \\
\hline \multirow[t]{2}{*}{ Nigeria (3) } & 0.825723 & 24.0597 & 15.41 & 20.04 & None** \\
\hline & 0.356052 & 4.841508 & 3.76 & 6.65 & At most $1^{*}$ \\
\hline \multirow[t]{2}{*}{ Sierra Leone (4) } & 0.775672 & 17.53911 & 15.41 & 20.04 & None* \\
\hline & 0.095 & 1.098023 & 3.76 & 6.65 & At most 1 \\
\hline \multirow[t]{2}{*}{ Guinea (5) } & 0.519918 & 17.5762 & 15.41 & 20.04 & None* \\
\hline & 0.063046 & 1.432657 & 3.76 & 6.65 & At most 1 \\
\hline \multirow[t]{2}{*}{ Liberia (6) } & 0.534657 & 9.24625 & 15.41 & 20.04 & None \\
\hline & 0.072801 & 0.831463 & 3.76 & 6.65 & At most 1 \\
\hline
\end{tabular}

Note. ${ }^{*}(*)$ denotes rejection of hypothesis at $5 \%(1 \%)$ significance level;

(1) L.R. indicates 2 cointegrating equation(s) at 5\% significance level;

(2) L.R. indicates 2 cointegrating equation(s) at 5\% significance level;

(3) L.R. indicates 2 cointegrating equation(s) at 5\% significance level;

(4) L.R. indicates 1 cointegrating equation(s) at 5\% significance level;

(5) L.R indicates 1 cointegrating equation(s) at 5\% significance level;

(6) L.R rejects any cointegration equation(s) at 5\% significance level.

In Gambia (Note 6) null hypothesis of no correlation between these two variables is rejected. Fiscal over the last two decades has strengthened with robust economic growth by 4\% rate in 2012 and relatively low inflation. Inflation has also increased slightly since January 2013 largely due to a weakening of the Gambian dalasi. However Gambia position is vulnerable since the macroeconomic stability isn't established as it reflects in a tight of the monetary policy stance and interest rate increase, overall the risk of debt is moderate.

Nigeria's release describes cointegration between fiscal deficit and debt. Its debt is sustainable because Nigeria has undertaken fiscal consolidation permitting a prudent borrowing regardless fiscal position. Furthermore, earnings from oil exports increased significantly as a result of higher world oil prices over the years has reduced government debt service payment. Based on the joint Bank-IMF low-income country debt sustainability analysis (DSA), Nigeria remains at a low risk of debt distress. But without significant policy measures for offsetting, a prolonged negative oil price shock may undermine the recent progress made in performing macroeconomic and debt sustainability. Therefore the Nigeria's fiscal balance is as weaker as any other member in WAMZ.

Guinea result indicates as well a cointegration between fiscal deficit and total debt. Instead of facing large shortfall revenue, the government adjusted its fiscal policy by reducing expenditure by delaying civil service wage increase and postponing plans for new recruitment in order to meet the basic balance deficit. The debt is weakly sustainable which could be explained that mainly a delay in disbursement of a large part ( $\$ 41$ million; 0.7 percent of GDP) of a grant from Abu Dhabi as disbursement conditions could not be met. Total net external assistance was 1.5 percent of GDP lower than anticipated, also reflecting higher debt service payments because of a delay in providing debt relief under the HIPC initiative.

Sierra Leone is one of best-performing country as we notice cointegration in table 3; fiscal consolidation efforts will continue through enhanced revenue mobilization and expenditure controls. It has taken relevant measures to meet fiscal program target as scaling back non-priority spending and domestically financed investment in order to avoid a buildup of unpaid bills and domestic debt. The government will ensure that borrowing policies are compatible with medium- to long term debt sustainability. Therefore, it will continue to give priority to grants and highly concessional loans in meeting financing needs, particularly for infrastructure projects.

Finally Liberia the null hypothesis of no cointegration is accepted even if we see that total revenue and grants are more than expected target by about half a percentage point of GDP. But total spending was somewhat above the target, owing in part to the absorption into the government payroll of some civil servants that were previously financed by donors and had to be financed by the use of deposits; as well as the increase in capital spending. In 
fact, Liberian dollar depreciated by 7 percent in June 2013. The depreciation pressures also reflect, in part, the rise in Government spending in Liberian dollars by about 38 percent in the first half of 2013, compared to 2012. In post-war period Liberia is reconstructing the economic and stabilizing macroeconomic policies which involve strong expenditures.

\section{Conclusion}

In summary, the outcome of the sustainability of fiscal policy by referring to accounting and PVBC approach, reveal that fiscal policy is sustainable in Gambia, Ghana, Nigeria, Sierra Leone, Guinea except Liberia. My findings support the views of Xiomara (2003) for Barbados and Antonio (2004) for European as well as Cuddington (1996) for developing countries. As such the policymaker should pursue their positive path by avoiding excessive decisions and also reinforce the establishment of prudent and consolidated fiscal management. Liberia's debt is unsustainable since this country faces a challenge of having a higher growth rate for expenditures than revenues, therefore they should realize some efforts to satisfy strict budget requirement. The policy implication first for Liberia is to continue to rationalize the expenditure and reduce debt financing of budget deficit. Second for WAMZ the debt needs to be monitored since it can destabilize the macroeconomic convergence efforts. In others words, they should set a upper bound to debt among others convergence criteria's, the WAMZ remains vulnerable to any adverse shocks which may result in increase of debt risk. As such the viable sustainability debt issue in WAMZ relies as well on the optimality of the entire Zone.

\section{References}

Ali, M. K., Evzen, K., \& Taner, M. Y. (2008). Fiscal convergence and discipline in monetary union: Evidence from the European Union. International Policy Center, 35.

Antonio, A. (2000). Fiscal policy sustainability: some unpleasant European evidence. Universidade Technica de Lisboa.

Antonio, A. (2004). Fiscal sustainability: the unpleasant European case. Research centre on the Portuguese Economy.

Asmaa, E. G. (2009). What is fiscal policy? IMF Finance \& Development.

Betty, C. D. (2000). A fiscal theory of currency crises. The University at Albany.

Betty, C. D., \& Christos, S. (2012). Fiscal risk in a monetary union. European Economic Review. http://dx.doi.org/10.1016/j.euroecorev.2012.04.004

Catherine, P., \& Paul, M. (2001). Monetary union in West Africa: an agency of restraint for fiscal policies? IMF.

Cuddington, J. T. (1996). Analysing the sustainability of fiscal deficit in developing countries. Economic Department, Georgetown University, Washington. D.C. 20059-1045.

Ezeabasili. \& Mojekwu. (2011). Analysis of fiscal deficits and interest rates in Nigeria. Journal of Economics and International Finance,3(4), 236-245. http://dx.doi.org/10.5897/JEIF

IMF. (2012a). Guinea, Joint Debt Sustainability Analysis.

IMF. (2012b). Liberia, Debt sustainability Analysis.

IMF. (2012c). Sierra Leone, Joint IMF/World Bank Debt Sustainability.

IMF. (2013a). Gambia, Debt sustainability analysis.

IMF. (2013b). Ghana, Debt sustainability analysis.

IMF. (2013c). Nigeria, Debt Sustainability Analysis.

James, D. H., \& Mayorie, A. F. (1986). On the limitations of government borrowing: a framework for empirical testing. American Economic Association.

James, S., Jan, L., \& Petr, S. (2010). Fiscal neglect in a monetary union. Economic Papers, 29(3), 1-9.

Jordali, G., \& Tommasco, M. (2008). Optimal monetary and fiscal policy in a currency union. Journal of International Economics, 76, 116-132. http://dx.doi.org/10.3386/w11815

Luisa, L. (2007). Optimal fiscal policy in a monetary union. Center for Fiscal Policy.

Russell, C. (2002). Overturning Mundell: Fiscal policy in a monetary union. Federal Reserve Bank of Minneapolis. 
Temitope, W. O. (2010). Monetary and Financial Integration in West Africa. London and New York: Routledge Taylor and Francis Group.

Xiomara, A., \& Kevin, G. (2003). Debt and fiscal sustainability in Barbados. Central bank of Barbados.

\section{Notes}

Note 1. WAMZ presumes 6 candidates countries (Ghana, Nigeria, Guinea, Gambia, Liberia, Sierra Leone) recognized as West African Monetary Zone (WAMZ) depend on mainly single-sector revenue, grants, undergo deficit and debt, little developed private sector and weak financial institutions.

Note 2. Temitope W.Oshikoya, 2010, page 84, "monetary and financial integration in West Africa".

Note 3 . As in EU, the threshold here is set to $60 \%$ of GDP.

Note 4 . This is the prediction made by the IMF experts.

Note 5. Include a large number of debt indicators and measures in terms of present value which isn't quiet depicting a particular position in a year.

Note 6. The Gambia received extensive debt relief under the enhanced Heavily Indebted Poor Countries (HIPC) Initiative and the Multilateral Debt Relief Initiative (MDRI) after reaching its HIPC completion point in December 2007.

\section{Copyrights}

Copyright for this article is retained by the author(s), with first publication rights granted to the journal.

This is an open-access article distributed under the terms and conditions of the Creative Commons Attribution license (http://creativecommons.org/licenses/by/3.0/). 